\title{
ROLE OF EARTH OBSERVATION DATA AND HYDROLOGICAL MODELING IN SUPPORTING UN SDGs IN NORTH WEST HIMALAYA
}

\author{
S.P. Aggarwal ${ }^{1 *}$, Praveen K. Thakur ${ }^{1}$, Bhaskar R Nikam ${ }^{1}$, Vaibhav Garg ${ }^{1}$, Arpit Chouksey ${ }^{1}$, Pankaj Dhote ${ }^{1}$, Sanjay Bisht ${ }^{1,2}$, Ankur \\ Dixit $^{1,3}$, Sidharth Arora ${ }^{1,4}$, Animesh Choudhury ${ }^{1,5}$, Vishal Sharma ${ }^{1}$, Prakash Chauhan ${ }^{1}$, A Senthil Kumar ${ }^{1,6}$
${ }^{1}$ Indian Institute of Remote Sensing, ISRO, 248001, 4-Kalidas Road, Dehradun, Uttarakhand, India - (spa, praveen, bhaskarnikam, vaibhav, arpit, pdh, prakash)@iirs.gov.in
${ }^{2}$ Honeywell Technology Solutions, Survey No. 115, Plot No. 11, 12/P, 15 \& 16P, Rd Numnber 2, Financial District, Nanakramguda, Hyderabad - 500019, Telangana, India - sanjaybist90@gmail.com
${ }^{3}$ Indian Institute of Technology Delhi, New Delhi, India - ankur572@gmail.com
${ }^{4}$ Indian Institute of Sciences, Bengaluru, Karnataka, India - siddarora.civil@gmail.com
${ }^{5}$ Department of Remote Sensing \& GIS, Vidyasagar University, Midnapore - 721102, West Bengal, India -
animesh.buddha@gmail.com
${ }^{6}$ Centre for Space Science and Technology Education in Asia and Pacific, CSSTEAP, IIRS Campus, 248001, 4-Kalidas Road, \\ Dehradun, Uttarakhand, India - senthil@iirs.gov.in
}

KEY WORDS: North West Himalaya, Earth Observation, Hydrological models, SDGs

\begin{abstract}
:
The sustainable usage and accurate assessment of water resources in North West Himalaya (NWH) is very important for respective policy makers. NWH receives precipitation from both southwest and northeast monsoon system. The detailed assessment of current and future water resources and hydrological cycle component for NWH river basins using earth observation (EO) satellites and hydrological models is very critical for attaining United Nations sustainable development goals (SDGs) namely, climate action, affordable and clean energy, clean water and sanitation and building resilient infrastructure. Present work highlights the role of various EO sensors and hydrological models and ground based instruments for improved assessment of water resources of $\mathrm{NWH}$ river basins. The complete inventory of NWH surface water (including glacier lakes of UK, HP), snow cover, delta SWE and glaciers database was accomplished with Remote Sensing (RS) datasets. Similarly, glacier velocity was estimated for all major glaciers of NWH using feature tracking and differential interferometry (DInSAR) methods. Fully distributed grid based hydrological model was setup for entire NWH and model calibration/validation was done for Beas, Satluj, Upper Ganga and Jhelum river basins. Quantification of relative contribution of snowmelt, glacier melt and rainfall-runoff was estimated for Bhagirathi basin upto Uttarkashi. An extensive network of automatic weather stations (AWS), 27 nos, 10 snow depth sensors, 04 digital water level recorders, two snow pack analysers and 06 long wave solar radiation sensors were installed in various sites of HP and UK for hydrometeorological data collection, model simulation and validation. A future climate change simulations were done for Beas and Jhelum basins using CORDEX 4.5 and 8.5 scenarios from 2006-2100. Number of flood peaks were found to be increasing in number as well as decrease in total snow fall.
\end{abstract}

\section{INTRODUCTION AND OBJECTIVES}

\subsection{Introduction}

The river basins of NWH are source or head water basin of many important rivers such as Ganga, Beas, Sutlej, Yamuna, Chenab, Indus, Jhelum, Tawi and Ravi. With the increase in population, tourism and industrial growth, the sustainable utilization of water resources should also increase, otherwise there is high probability of flood during monsoon and increased water stress in the summer in coming years. The assessment of $\mathrm{NWH}$ region using traditional ground based observations of hydro-meteorological parameters such as precipitation, snow depth, temperature, wind speed/direction, river flow, glacier ice thickness and reservoir storage are paramount for better assessment as well as improving results of hydrological and other land surface models (Thakur et al., 2019). But the limited spatial distribution of such networks and high maintenance cost of such instruments hinders there dense basin level deployment as per world meteorological standards. The Earth Observation (EO) data (Thakur et al., 2017) along with limited ground observations, hydrological models (Singh., 2018), data assimilation (Lahoz and De Lannoy, 2014) and future climate scenarios (Aggarwal et al., 2016) can play a major role for systematic and regular monitoring of water resources of NWH river basins and assessment of water availability in present and future scenarios (McCabe et al., 2017; Wester et al., 2019). The high mountainous regions of NWH above 1800 m elevation usually receives significant snowfall and many mountain glaciers are located in this region above $4000 \mathrm{~m}$ elevation, which are monitored primarily using remote sensing (RS) datasets (Frei et al., 2011; Bolch et al., 2012). The melt water from snow/ice bound regions provide makes significant contribution to river flows in this region, esp., during spring-summer season (Singh et al., 2002; Jain et al., 2010; Aggarwal et al., 2014; Thakur et al., 2017). The surface water in river, natural lakes and man-made reservoirs is used for various needs such as drinking, hydro power, irrigation, industry and recreation. The remote sensing along with ground data provides information about surface waters spatio-temporal extent, reservoir sedimentation and water quality parameters (McFeeters, 1996; Govindha Raj et al., 2013; Pandey et al., 2016; Garg et al., 2017). The UN sustainable development goals (SDGs) such as climate action, availability of clean water, affordable renewable energy, sanitation and building resilient infrastructure (https://sustainabledevelopment.un.org/sdgs) are directly linked 
with fresh water availability and dynamics of surface water, snow cover and glacier ice in NWH region and its river basins. The increasing rates of extreme weather events such as extreme rainfall, flash flooding, Glacier Lake outburst floods (GLOF) in the last 30 years have pointed towards role of such tools and climate projections to develop suitable adaption and mitigation measures in NWH (Wester et al., 2019).

\subsection{Objectives}

With the given background about importance of RS, ground observations and modeling techniques, following objectives are addressed in this work, which is a part of ISRO sponsored research project in NWH (Navalgund et al., 2019; Saha and Kumar, 2019; Aggarwal et al., 2019). First the extent and dynamics of surface water, snow cover and inventory of glaciers of NWH region is compiled from various remote sensing and other open GIS sources. Next the glacier velocity, snow depth and change in SWE are estimated using remote sensing and for few glaciers ice thickness was also calculated. Next the grid based fully distributed hydrological modeling is done for $\mathrm{NWH}$ river basin to assess present climate water availability and also future climate hydrological fluxes. To validate the results of remote sensing derived hydrological variable and hydrological model results, the ground data from various field agencies as well as hydro-meteorological instruments installed in H.P. and U.K. states of India by IIRS-ISRO are used. Details of data used, methods and results are given in the next sections.

\section{MATERIAL AND METHODS}

\subsection{Study area}

The three states of North West Himalaya (NWH) i.e., Uttarakhand (UK), Himachal Pradesh (H.P), Jammu and Kashmir (J \& K) and one union territory (UT) of Ladakh along with river basins falling in these states are part of the study area. Some of the river basins like Sutlej and Indus have their origin and basin boundary outside Indian political boundary are also considered for full basin hydrological modeling studies (figure 1 ). Rest all database of snow, surface water and glaciers are considered within Indian political boundaries only.

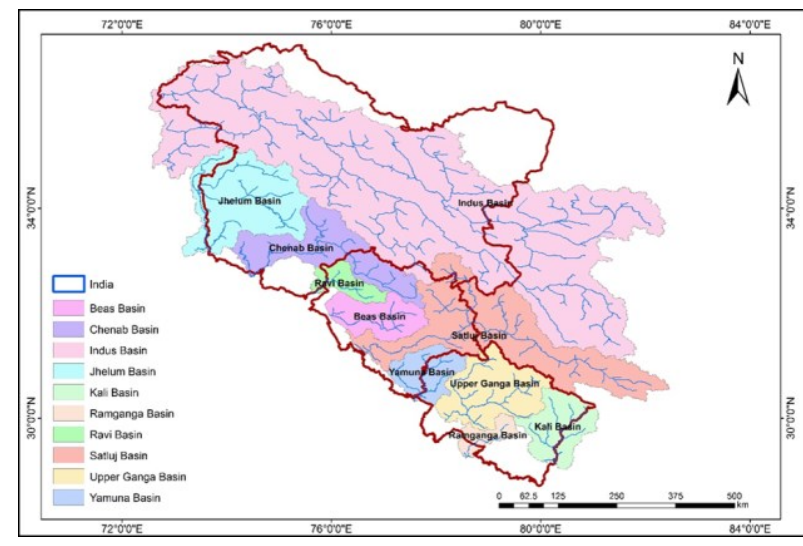

Figure 1. NWH region with state and river basin boundaries.

\subsection{Material and data used}

The various data products from various sources are used in this work. The primary RS data was provided by National Remote Sensing Centre (NRSC) Hyderabad, United Sates Geological Survey (USGS) for Landsat and Sentinel-2, Alaska SAR
Facility (ASF) vertex node for Sentinel-1 SAR data, Joint Research Centre (JRC) in Ispra, Italy for global surface water layer. National Snow and Ice Data centre (NSIDC) provided the MODIS based snow products. Complete list is given in table 1 .

\begin{tabular}{|c|c|c|c|}
\hline Data type & $\begin{array}{l}\text { Satellite/Sensor } \\
\text { Ground sensor }\end{array}$ & $\begin{array}{l}\text { Data } \\
\text { product }\end{array}$ & $\begin{array}{l}\text { Data } \\
\text { Source(s) }\end{array}$ \\
\hline $\begin{array}{l}\text { Optical RS } \\
\text { images and } \\
\text { derived } \\
\text { products as } \\
\text { LULC and } \\
\text { DEM }\end{array}$ & $\begin{array}{l}\text { Landsat } \\
\text { (TM/ETM+/OLI) } \\
\text { Sentinel-1 (MSI) } \\
\text { IRS (LISS-III, IV, } \\
\text { and AWiFS) } \\
\text { ASTER, ALOS- } \\
\text { PALSAR, PRISM }\end{array}$ & $\begin{array}{l}\text { Geocoded } \\
\text { L-1 data } \\
\text { And DEM } \\
\text { products }\end{array}$ & $\begin{array}{l}\text { USGS EE; } \\
\text { ESA } \\
\text { Copernicus } \\
\text { and USGS } \\
\text { NRSC }\end{array}$ \\
\hline SAR images & $\begin{array}{l}\text { Sentinel-1, } \\
\text { RISAT-1 } \\
\text { ALOS-PALSAR-2 }\end{array}$ & $\begin{array}{l}\text { SLC \& } \\
\text { GRD } \\
\text { products }\end{array}$ & $\begin{array}{l}\text { ASF, ESA, } \\
\text { NRSC and } \\
\text { JAXA }\end{array}$ \\
\hline Snow Cover & $\begin{array}{l}\text { Terra/Aqua } \\
\text { MODIS } \\
\text { IRS-AWIFS }\end{array}$ & $\begin{array}{l}\text { Daily, } 8 \\
\text { day and } 15 \\
\text { day SCA } \\
\text { product }\end{array}$ & $\begin{array}{l}\text { NSIDC } \\
\text { NRSC/ } \\
\text { Bhuvan }\end{array}$ \\
\hline $\begin{array}{l}\text { Glacier } \\
\text { extent }\end{array}$ & $\begin{array}{l}\text { Terra-ASTER } \\
\text { Landsat- } \\
\text { TM/ETM+ } \\
\end{array}$ & $\begin{array}{l}\text { GIS .shp } \\
\text { files for } \\
\text { glaciers }\end{array}$ & $\begin{array}{l}\text { RGI } \\
\text { version } 6\end{array}$ \\
\hline $\begin{array}{l}\text { Surface } \\
\text { water }\end{array}$ & $\begin{array}{l}\text { Landsat } \\
\text { (TM/ETM/OLI) }\end{array}$ & $\begin{array}{l}\text { Water } \\
\text { layers }\end{array}$ & JRC - Ispra \\
\hline River flow & $\begin{array}{l}\text { River Gauging } \\
\text { sites }\end{array}$ & $\begin{array}{l}\text { River WL } \\
\text { and flow } \\
\text { data }\end{array}$ & $\begin{array}{l}\text { BBMB, } \\
\text { J\&K IFCD } \\
\text { and CWC }\end{array}$ \\
\hline $\begin{array}{l}\text { Meteorologic } \\
\text { al data }+ \\
\text { future } \\
\text { climate data }\end{array}$ & $\begin{array}{l}\text { AWS and gridded } \\
\text { datasets }\end{array}$ & $\begin{array}{l}\text { IIRS-AWS } \\
\text { IMD-Grid, } \\
\text { ERA-Int; } \\
\text { Aphrodite; } \\
\text { CORDEX }\end{array}$ & $\begin{array}{l}\text { IMD, } \\
\text { ISRO and } \\
\text { ECMWF }\end{array}$ \\
\hline $\begin{array}{l}\text { Snow } \\
\text { parameters }\end{array}$ & $\begin{array}{l}\text { SPA/SWE/SD } \\
\text { gauge }\end{array}$ & $\begin{array}{l}\text { Point data } \\
5-15 \mathrm{~min} \\
\text { interval } \\
\end{array}$ & $\begin{array}{l}\text { IIRS-ISRO } \\
\text { SAC-ISRO }\end{array}$ \\
\hline
\end{tabular}

Table 1. List of various datasets along with its sources

The hydro-meteorological data such as observed river water level and discharge are provided by Bhakra Baes Management Board (BBMB) for Beas and Sutlej river basins, J \& K Irrigation and flood control department (J\&K IFCD) for Jhelum and Chenab river basins and Central Water Commission (CWC) for Ganga river basin. The meteorological data was available from Automatic Weather Station, AWS (27 numbers, figure 2) network of IIRS-ISRO, with 10 AWS having snow depth sensor and 9 AWS with long wave radiation sensors, in addition to rainfall, air temperature, wind speed/direction and short wave solar radiation sensors. The data from these sites are available from 2014-2020 with two sites (Bhota, Hamirpur and Kothi, Manali) having longer data (August 2014 onwards) records as compared to others due to variable date of installation of these AWSs. Two sites at Dhundi, Manali (HP) and Tungnath, Uttarakhand also have Snow Pack Analyser (SPA) installed during April 2015 and November 2018, providing continuous data on snowpack properties such as snow depth, snow density and snow water equivalent (SWE) at full depth plus two variable depths (figure 3). Additionally, few digital water level recorders (DWLR) were also installed at downstream of glacier snouts at Chhota Shigri and Patsio glaciers in upper Chenab river basin in autumn of 2016 (figure 21, appendix - I). 


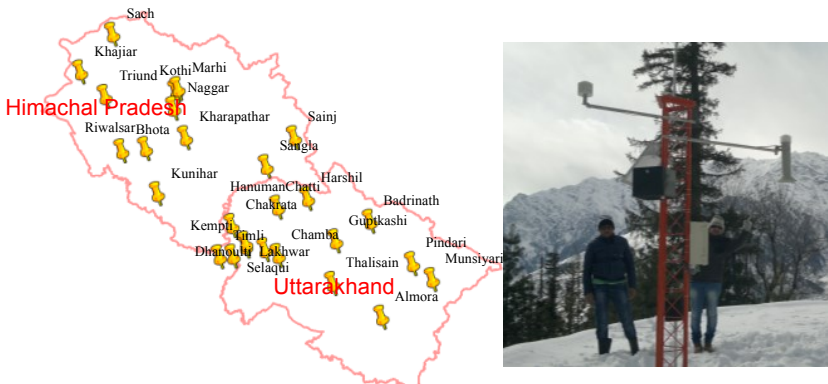

Figure 2. Location of installed IIRS-ISRO AWS network in HP \& UK with filed picture of Kothi AWS with snow depth sensor.

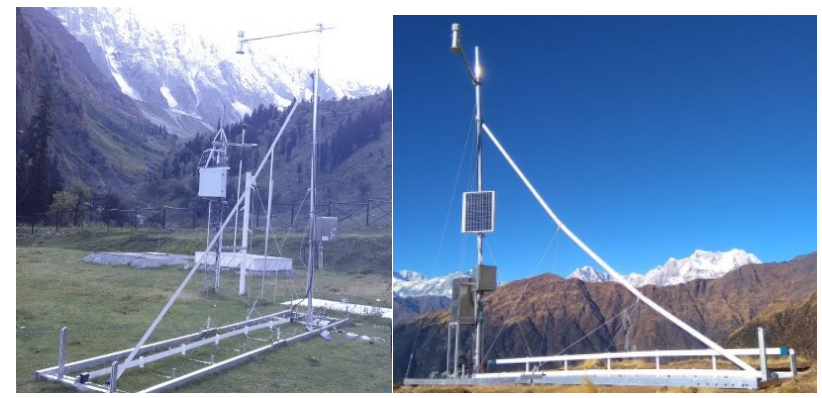

Figure 3. Installed SPA at Dhundi, Manali and Tungnath, UK.

The weather data from these sites is available in near real time using mobile networks at time interval of 5-30 mins as per requirements and strength of terrestrial communication networks. The SPA instrument was damaged due to heavy snowfall during winter of 2019 , during which last recorded snow depth by sensor was $2.9 \mathrm{~m}$, so data from this sensor is available from 2015-2019 time. Some of the ground data from IIRS sensors is given in appendix 1 along with field photographs.

This data from RS sensors and data products is used to create base line maps and time series maps for various hydrological parameters such as land use land cover (LULC), snow cover, surface water, glacier facies, glacier velocity and terrain related parameters for watersheds and rivers. The river flow, snow instruments data is used for calibration and validation of hydrological and land surface models. Meteorological data from IMD and IIRS-ISRO AWS networks is used for bias correction, and comparison with re-analysis products such as ERA-Interim and ERA-5 and this data is input parameters for simulating hydrological models.

\subsection{Methodology}

The methods used to achieve each objective is described briefly in this section. First sub-section gives approach for mapping and monitoring of surface water and snow cover using timeseries remote sensing datasets and products. Next the approach used for glacier monitoring and its dynamics study involving estimation of glacier velocity and radar zones is described. Finally, the approach used in hydrological and climate change impact study is given.

\subsubsection{Method for snow cover and surface water mapping and monitoring}

The snow cover and surface water are primarily used Normalized Difference Snow Index, NDSI (Dozier, 1984) and Normalized Difference Water Index (McFeeters, 1996). These indices along with other bands information available in Landsat, MODIS and AWiFS sensors are used in a multi-criteria methods to derive the daily, weekly to fortnightly snow products at NSIDC (Hall et al. 2002, 2010; Subramaniam et al., 2011, Nikam et al., 2017) and NRSC-Bhuvan and long term surface water products at JRC (Pekel et al., 2016). Wet and dry snow cover mapping was done using C-band SAR data from RISAT-1 and Sentinel-1 datasets, using methods described in Thakur et al., (2017, 2018). As large part of area of NWH comes under forested catchments, retrieval of snow under forest was attempted using L-band SAR data on experimental basis (Ganguly, 2012).

\subsubsection{Method for glacier monitoring and dynamics}

The glacier boundaries are taken from version 6 of RGI glacier inventory (RGI-2017). This data, which represent glacier extent for the time frame of 2000-2004, was updated for few glaciers of NWH using base RS data from IRS, Landsat and Sentinel-2 multi spectral images. The updated glacier extent are used for computation of glacier mass balance using accumulation area ratio method (AAR) for one of the bench mark glacier, Chhota Shigri glacier and computation of accumulation, ablation areas using equilibrium line altitude for glaciers of Upper Beas and Chenab river basins. Band ratio and NDSI indices are also used for glacier ice classification and snout identification was done using NDWI indices and visual interpretation using optical data. The glacier velocity and radar zones or glacier facies were generated using time series of ortho-rectified optical data and synthetic aperture radar (SAR) ground range detected (GRD) and single look complex (SLC) products. The feature tracking and offset tracking method (Scherler et al., 2008; Li et al., 2014) was used with optical and SAR-GRD products and DInSAR method (Joughin et al., 2009; Thakur et al., 2018) was used with SAR-SLC data. Glacier facies zones were created using SAR based composite methods (Patrington, 1998)

\subsubsection{Method for hydrological modeling and climate change impact studies}

The hydrological modelling of North Western Himalaya is done using the Variable Infiltration Capacity (VIC) Model. The grid size considered for the study is $0.025^{\circ} \mathrm{X} 0.025^{\circ}$. The study area for the study is shown in figure 1 .

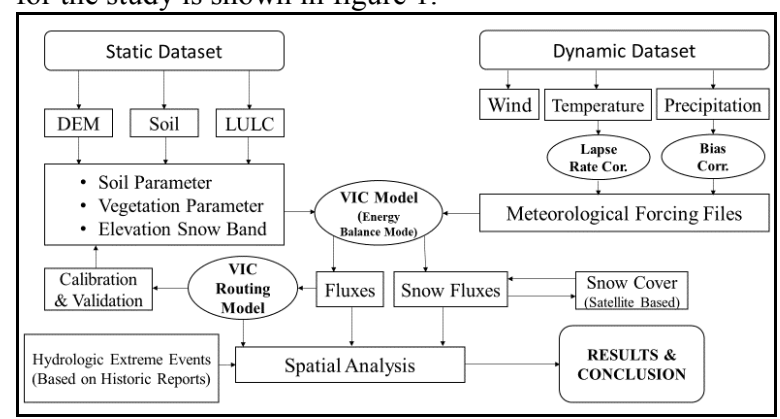

Figure 4. Overall approach for hydrological modeling

The methodology (figure 6) involves the bias correction of the ERA- Interim precipitation dataset using the CORDEX and the also applying the lapse rate correction in the ERA- Interim temperature dataset before the forcing generation. The Digital Elevation Model (DEM), Soil Parameter, Land Use Land Cover, Snow Cover etc. are utilized in the generation of the model input parameter files. The simulations for the VIC model are done for the historic (1979- 2000), present (2001 - 2018) and future $(2019$ - 2099) time period. 


\section{RESULTS AND DISCUSSIONS}

The section briefly describes the main results of the this project, as defined under three major objectives and methods given in section 1 and 2. The results are part of the work done as part of ISRO project in NWH, as defined in section 1.2. First the results of each activity are presented, followed by discussion on the same topic with comparison from field observations and other ground observations.

\subsection{Results of SCA and SW mapping}

The time series of AWiFS and MODIS SCA products are used to generate the NWH snow cover at 8-day (figure 5,6) and 15 day interval from 2000 and 2012 onwards at $500 \mathrm{~m}$ and 3 minute spatial resolution. IMS based multi-sensor daily $1-\mathrm{km}$ resolution SCA products (US National Ice centre, 2008) are analysed from 2014 onwards. The dry/wet snow and snow under forest as derived from SAR data is also estimated using RISAT-1 and ALOS-PLASAR-1 datasets and are shown in figure 7 .

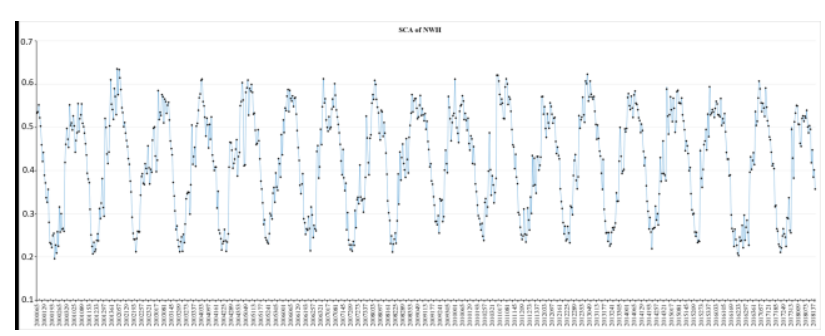

Figure 5. Overall variation in SCA in NWH from 2000-2018.

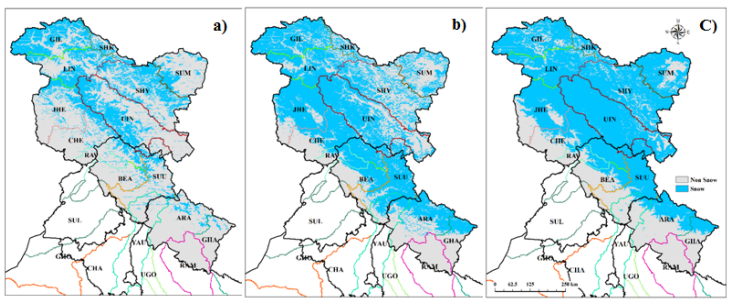

Figure 6. SCA during 2016-2017 season (a) November 25December 02 2016, (b) January 09-16, 2017, (c) February 10 17, 2017 (Nikam et al., 2017).
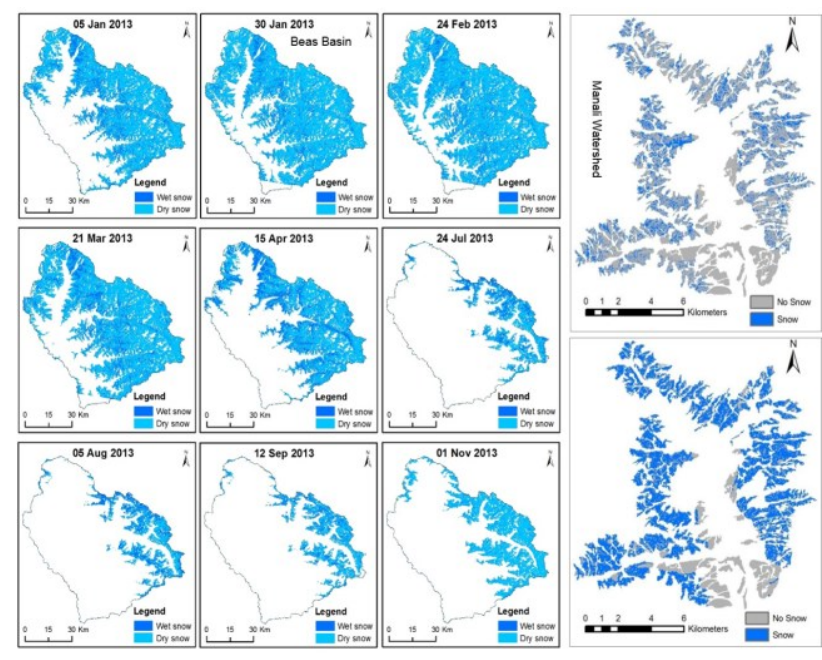

Figure 7. Snow cover area for Beas river basin as derived from RISAT-1 data; SCA inside the forest patch of Manali watershed on 18 February 2011. a) Without forest minimization b) after forest minimization (Thakur et al., 2017, Ganguly, 2012).

The maximum and Minimum SCA of entire NWH comes as 60$67 \%$ and $20-22 \%$ of total NWH area during 2000-2018 time. The accuracy of various SCA products was validated with limited ground truth form from available IMD and IIRS weather stations data as well as field campaigns and media reports. Limited validation was also done using cloud free Landsat and Sentinel-1 optical datasets. The coefficient of determination of 0.85 to 0.95 was achieved for satellite based SCA products.

The surface water occurrence as derived from JRC global surface database is shown in figures 8 and 9. Some extreme flood events and Tehri reservoir which was $1^{\text {st }}$ filled in 2006, shows low \%age of water occurrence, whereas permanent lakes, perennial rivers and reservoirs operational before 1985 are showing highest \%age occurrence.

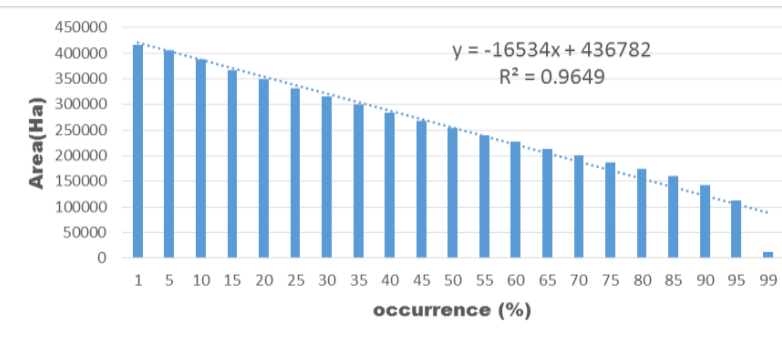

Figure 8. Surface water occurrence of NWH from 1984 to 2015
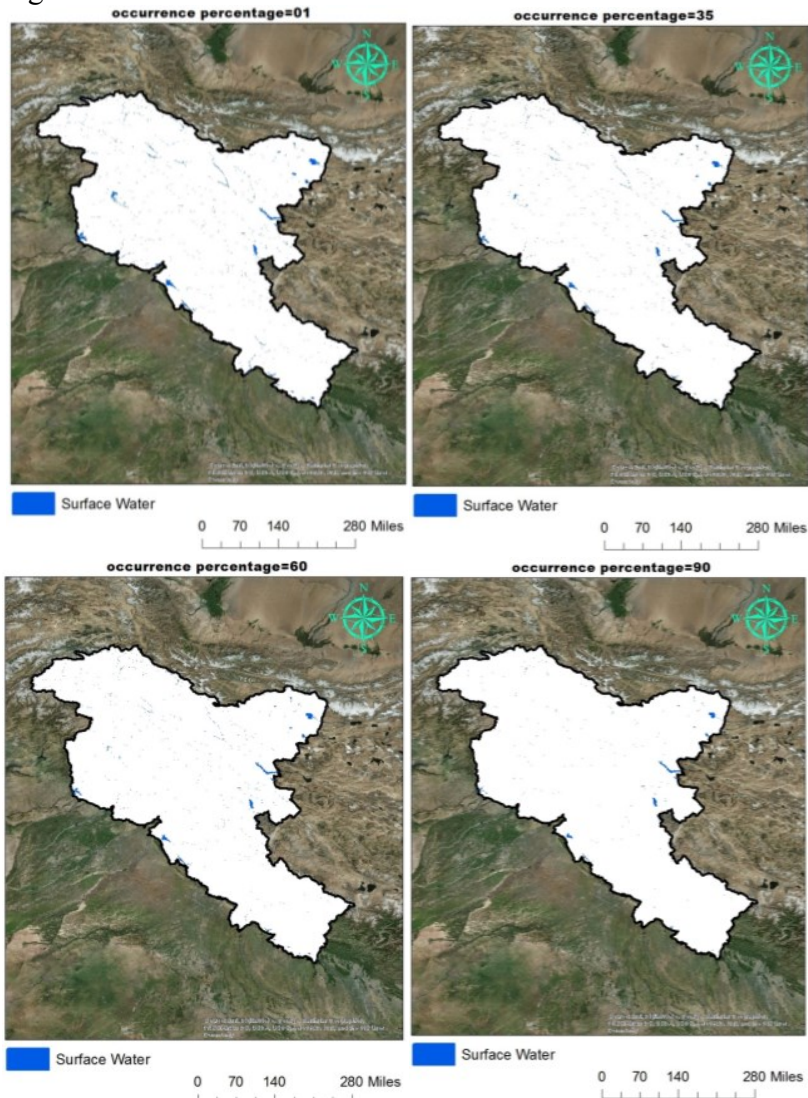

Figure 9. Surface water occurrence (\%) of NWH from 1984 to 2015 at 01, 35, 60 and 99 percentage levels. Higher the occurrence percentage, more perennially or permanent the water body. 


\subsection{Results of glacier monitoring and dynamics}

The glaciers of NWH (figure 10) as per RGI version 6 global inventory with an area greater than $0.01 \mathrm{~km}^{2}$, covers a total area of $29273 \mathrm{~km}^{2}$ (8.83\% of total NWH area) with total count of 19747. The Siachen group of glaciers in Karakoram Range of Ladakh, UT has biggest area $\left(1078 \mathrm{~km}^{2}\right)$, and Ladakh UT has highest land area $(12.61 \%)$ under glaciers as compared in H.P. and U.K. states.

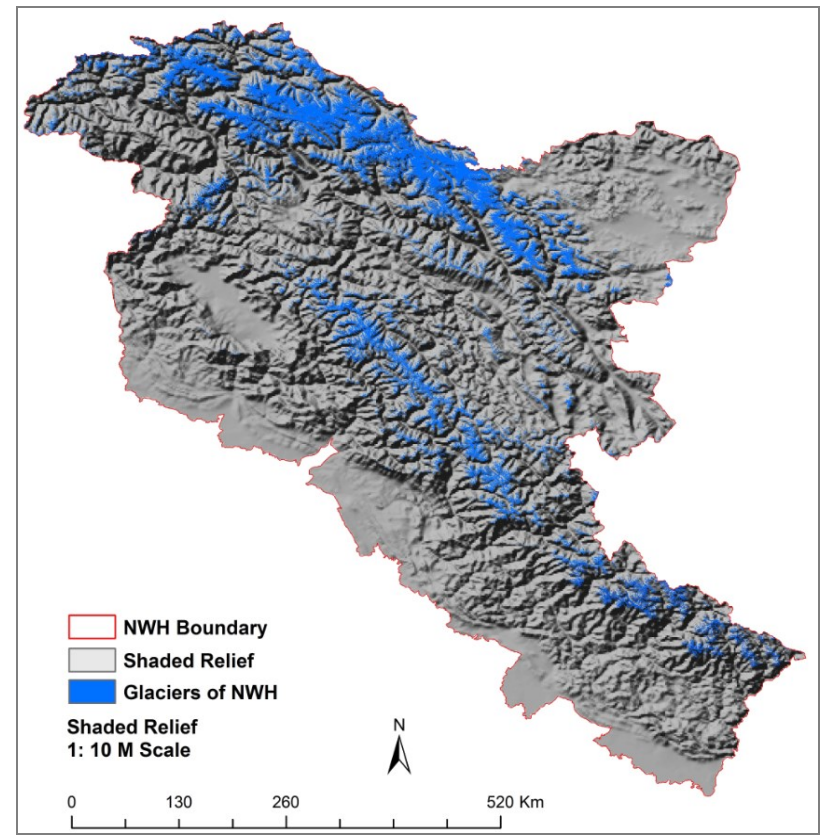

Figure 10. Glaciers of NWH region (Source: RGI-version 6).

The basic glacier inventory is updated for area of some major glaciers in upper catchments of rivers Chenab, Beas, Shyok, and Ganga using 2015-2019 Landsat-8 and Sentinel-2 data, with majority showing small reduction in area. Major work in glacier dynamics is done in two parts, first the glacier facies zones are presented here for upper Chenab and Beas basins. The S-1 SAR data for year 2015 (Feb., April and August) is used for colour composite (figure 11) and further classification of this composite was used to create glacier facies map for the year 2015 (figure 12) with accuracy of $85 \%$ (Jasmine, 2018). The mean Equilibrium Line Altitude (ELA) for the year for entire area comes out as $5066 \mathrm{~m}$ for the year 2015 . The area of various zones is estimated as accumulation zone $\left(504.93 \mathrm{~km}^{2}\right)$, ablation zones $\left(308.16 \mathrm{~km}^{2}\right)$ and transitional firn zones $\left(120.16 \mathrm{~km}^{2}\right)$.

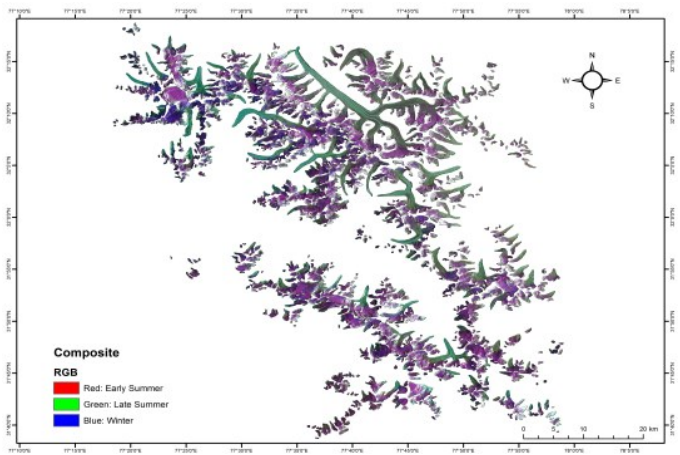

Figure 11. Glacier radar zones as seen in color composite

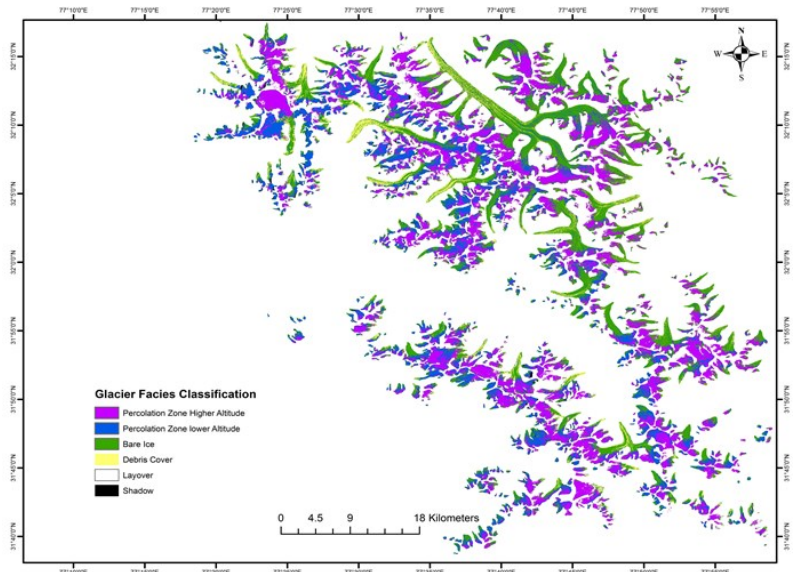

Figure 12. Classified radar zones or facies for upper Chenab, Beas basins as derived from SAR composite for year 2015.

The second part on glacier velocity as derived using Sentinel-2 MSI data, with feature tracking method for few major large glaciers, Siachen and Baltaru in Ladakh, UT, of NWH are shown in figure 13, with mean velocity in ranges of 150-170 $\mathrm{m} /$ year. Some areas of glaciers in accumulation zone having permanent snow is showing de-correlation. The DInSAR method was also implemented for 2016-17 time for major glaciers of NWH, with line of sight (LoS) glacier velocity shown as an example for Gangotri glacier (figure 14).

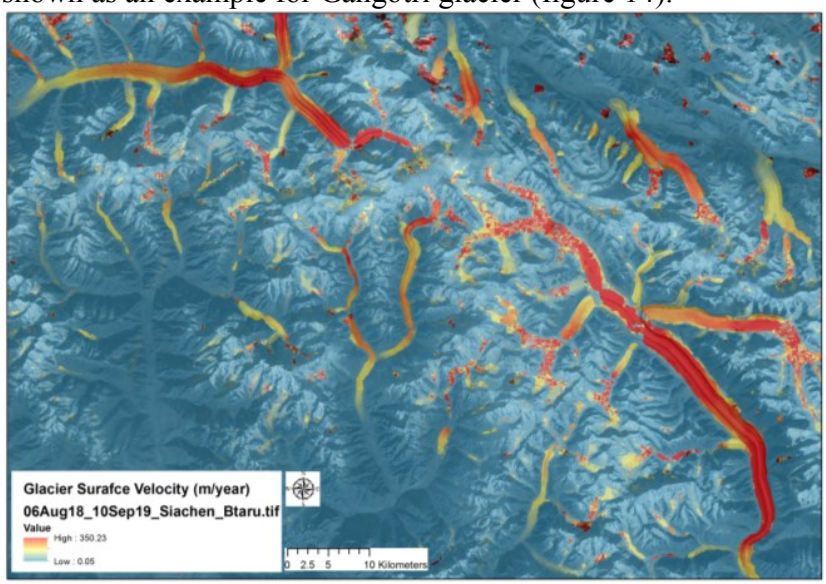

Figure 13. Glacier velocity for glaciers of Karakoram region.
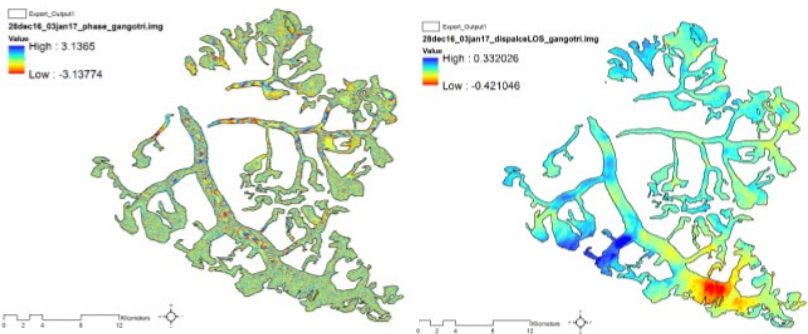

Figure 14. Interferogram and LoS glacier velocity for Gangotri Glacier using Sentinel-1 SAR data (Dec 2016-Jan. 2017)

\subsection{Results of Hydrological Modeling}

The methodology involves the bias correction of the ERAInterim precipitation dataset using the CORDEX and the also applying the lapse rate correction in the ERA- Interim temperature dataset before the forcing generation. The Digital Elevation Model (DEM), Soil Parameter, Land Use Land 
Cover, Snow Cover etc. are utilized in the generation of the model input parameter files. The simulations for the VIC model are done for the historic (1979-2000), present (2001 - 2018) and future $(2019-2099)$ time period. The bias correction has shown improvement in the model behavior and the lapse rate correction has shown improvement in the snow fluxes of the model. The model setup is calibrated at the Beas, Jhelum, Upper Ganga and Sutlej river basins. The snow parameters obtained from the VIC simulations are plotted and have shown good correlation with the observed parameters. The Snow Water Equivalent (SWE) and Snow Depth (SD) are shown in figure 15 and figure 16.

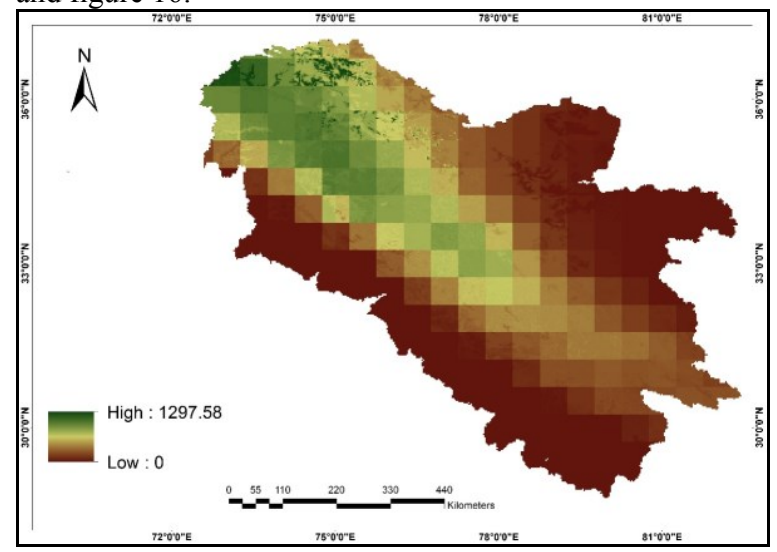

Figure 15. SWE (in $\mathrm{mm}$ ) map for NWH river basins.

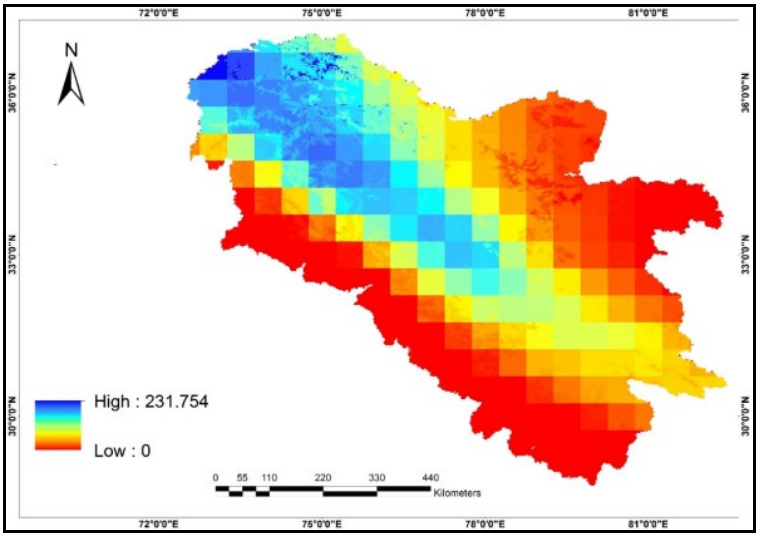

Figure 16. SD (in cm) map for NWH river basins.

It has been observed that there is increase in the hydrological extremes from historic to present time period and it will increase with more alarming rate in the future time period (figure 17). The region lying in the North Western Himalaya will experience high number of rainfall extremes and will also experience the after effects of disturbed hydrological cycle having shorter span of rainy days with large number of extreme rainfall events. The snow melt contribution has also shown increase in the months of early ablation period i.e. February to April and snow melt contribution had decreased drastically in the months of May - June. These events will pose danger of flash floods in the low lying or downstream of the rivers.

The partitioning of total discharge at in terms of glacier melt, snowmelt and rainfall plus base flow was also done for Bhagirathi basin upto Uttarkashi using snow-glacier version of VIC model at grid resolution of $1 \mathrm{~km}$. These simulations from 2004-2007 time gave contribution of $15.02 \%$ (glacier), $27.7 \%$ (snow) and $57.7 \%$ (rain-runoff) respectively on annual basis.

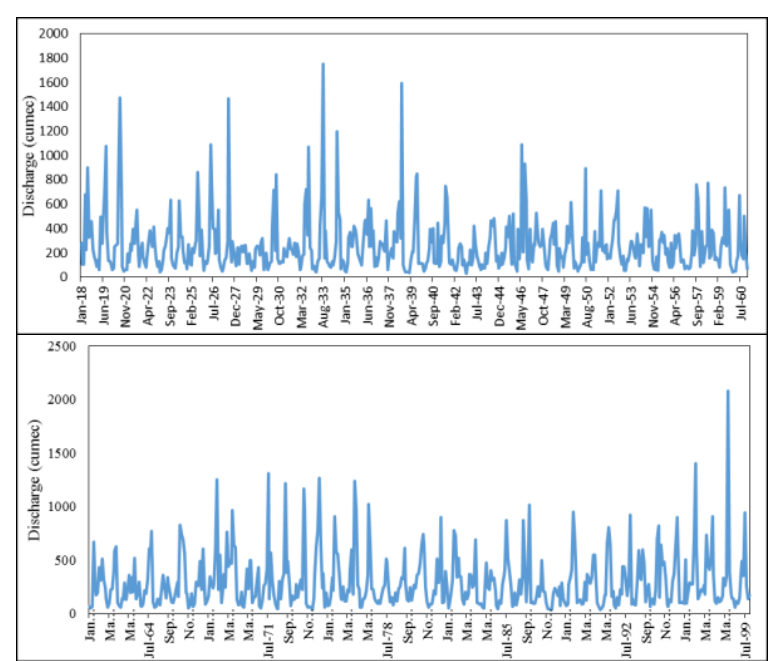

Figure 17: Beas basin hydrographs for future simulations.

\section{CONCLUSION AND FUTURE SCOPE}

Sustainable usage and accurate assessment of water resources in NWH is very important for respective policy makers. The present work highlights the use of remote sensing and hydrological models for hydrological and water related land surface parameters estimation. The spatio-temporal inventory of surface water, snow cover, glaciers and hydrological fluxes (for historic, present and future time periods) has been generated in ISRO funded project and some of the results are presented in this paper. These datasets and hydrological fluxes can be utilized by state and central water departments, disaster management agencies, NGOs and academia for accurate and improved assessment of NWH river basins water resources. Therefore, these datasets and hydrological information can complimenting and contributing towards the attainment of UN SDGs in NWH.

In future, there is strong scope of making RS based surafce water, snow/glacier surface elevation and their mass change estimation using Icesat- 2 and gravity based satellite, Grace 1 and 2. The current hydrological simulations for historic and present climate are done with ERA-Interim data, but as in 2019, ERA-5.0 data have been released, which can be used for improved estimates of water balance in this region. Simulation of water use and demand by several sectors such as drinking water, irrigation, hydro- power and industrial use for present and future scenarios can give the better picture about the sustainable use of the water. Similarly, the field level experiments at watershed scale both in glacierized and nonglacierized need to be developed to better understand the hill slope, snow and glacier hydrology of these mountainous regions. This will help in better parameterization and improving the accuracy of hydrological models for NWH.

\section{ACKNOWLEDGEMENTS}

Authors acknowledge the support from Chairman, Indian Space Research Organization (ISRO) for their kind support to complete this research work. This work is done as part of Indian Space Research Organization (ISRO) funded Earth Observation and Applications Mission (EOAM) project on "Monitoring and assessment of ecosystem processes and services in NorthWestern Himalaya, sub-theme 4 on water resources status and availability". Satellite data of MODIS SCA product was download from National Snow and Ice Data Centre (NSIDC), 
AWIFS SCA product was taken from Bhuvan-open EO data portal, Landsat and Sentinel-1 data from USGS Earth Explorer, Glacier inventory from Randolph glacier inventory, Surface water layers from JRC and GEE and Future climate change data was taken from ESGF's Swedish Meteorological and Hydrological Institute (SMHI) CORDEX data node. Ground data on river flow was provided by BBMB and meteorological data grids were provided by IMD. AWS and Snow Depth, SWE data was also taken from ISRO's hydro-meteorological stations.

\section{REFERENCES}

Aggarwal, S. P., Garg, V., Thakur, P.K. and Nikam, B.R., 2019. Northwest Himalayan Ecosystems: Issues, Challenges and Role of Geospatial Techniques. Chapter 6 in Book, Remote Sensing of Northwest Himalayan Ecosystems Editors: Navalgund, R.R., Kumar, Senthil, Nandy, Subrata (Eds.), 1st ed. 2019, LII, 564 p. 301. DOI: 10.1007/978-981-13-2128-3.

Aggarwal, S.P., Thakur, P.K., Nikam, B.R. and Garg, V., 2014. Integrated approach for Snowmelt Runoff Estimation using Temperature Index Model, Remote sensing and GIS. Curr Sci 106(3), 397-407.

Bolch, T., Kulkarni, A., Kääb, A., et al (2012) The state and fate of Himalayan glaciers. Science, 80-336, 310-314.

Dozier, J.F., 1984. Snow reflectance from Landsat-4 thematic mapper. IEEE Trans Geosci Remote Sens., 22(3), 323-328.

Frei, A., Tedesco, M., Lee, S., Foster, J.L., Hall, D.K., Kelly, R.E. and Robinson, D.A., 2011. A review of global satellitederived snow products. Adv Space Res., 50(8), 1007-1029.

Frey, H., Machguth, H., Huss, M., Huggel, C., Bajracharya, S., Bolch, T., Stoffel, M., 2014. Estimating the volume of glaciers in the Himalayan-Karakoram region using different methods. The Cryosphere, 8(6), 2313-2333.

Ganguly, S., 2012. Retrieval of forest backscatter from SAR data to improve snow cover area estimation in the coniferous forest of North Western Himalaya catchment. MSc. Thesis, Faculty of Geo-Information Science and Earth Observation of the University of Twente and Indian Institute of Remote Sensing, Dehradun. 72 pages.

Gantayat, P., Kulkarni, A. V., and Srinivasan, J., 2014. Estimation of ice thickness using surface velocities and slope: Case study at Gangotri Glacier, India. Journal of Glaciology, 60(220), 277-282.

Garg, V., Kumar, A.S., Aggarwal, S.P., Kumar,V., Dhote, P.R., Thakur, P.K., Nikam, B.R., Sambare, R.S., Siddiqui, A., Muduli, P.R. and Rastogi, G., 2017. Spectral Similarity Approach for Mapping Turbidity of an Inland Waterbody. Journal of Hydrology, 550, 527-537.

Govindha Raj, B.K., Kumar, V.K. and Remya, S.N., 2013. Remote sensing based inventory of glacial lakes in Sikkim Himalaya: semi-automated approach using satellite data. Geomatics, Natural Hazards and Risk, 4(3), 241-253.

Hall, D.K., Riggs, G.A., Foster, J. and Kumar, S.V., 2010. Development and evaluation of a cloud-gap-filled MODIS daily snow-cover product. Remote Sens Environ, 114, 496-503.

Hall, D.K., Riggs, G.A., Salomonson, V.V., DiGirolamo, N. and Bayr, K.J., 2002. MODIS snow cover products. Remote Sens Environ., 83:181-194.
Jain, S.K., Goswami, A., Saraf, A.K., 2010. Snowmelt runoff modeling in a Himalayan basin with the aid of satellite data. International Journal of Remote Sensing. 31(24): 6603-6618.

Jain, S.K., Singh, P. and Seth, S.M. (2002) Assessment of sedimentation in Bhakra Reservoir in the western Himalayan region using remotely sensed data. Hydrological Sciences Journal, 47(2), 203-212.

Jasmine, 2018. Glaciers Dynamics Monitoring using Optical and Radar Dataset. MSc. in geo-information system and remote sensing thesis, Amity University and IIRS Dehradun. 84 pages.

Joughin, I., Smith, B.E. and Abdalati, W., 2010. Glaciological advances made with interferometric synthetic aperture radar. Journal of Glaciology, 56(200), pp. 1026-1041.

Lahoz, W.A. and De Lannoy, G.J.M., 2014.Closing the Gaps in Our Knowledge of the Hydrological Cycle over Land: Conceptual Problems. Surv Geophys 35, 623-660.

Li, J., Li, Z. W., Ding, X. L., Wang, Q. J., Zhu, J. J., \& Wang, C. C., 2014. Investigating mountain glacier motion with the method of SAR intensity tracking: Removal of topographic effects and analysis of the dynamic patterns. Earth-Science Reviews, 138, 179-195.

McCabe, M. F., Rodell, M., Alsdorf, D. E., Miralles, D. G., Uijlenhoet, R., Wagner, W., Lucieer, A., Houborg, R., Verhoest, N. E. C., Franz, T. E., Shi, J., Gao, H., and Wood, E. F., 2017. The future of Earth observation in hydrology, Hydrol. Earth Syst. Sci., 21, 3879-3914.

McFeeters, S.K. (1996) The use of the normalized difference water index (NDWI) in the delineation of open water features. Int. J. Remote Sens. 17, 1425-1432.

Navalgund, R.R., Kumar, A.S. and Nandy, S., (Eds.) 2019. Remote Sensing of Northwest Himalayan Ecosystems. 1st ed. 2019, LII, 564 p. 301. DOI: 10.1007/978-981-13-2128-3.

Nikam, B.R., Garg, V., Gupta, P.K., Thakur, P.K., Kumar, A.S., Chouksey, A., Aggarwal, S.P., Dhote P. and Purohit, S., 2017. Satellite-based mapping and monitoring of heavy snowfall in North Western Himalaya and its hydrologic consequences, Current science, 113(12), 2328-2334.

Pandey, A., Chaube, U.C., Mishra, S.K. \& Kumar, D., 2016 Assessment of reservoir sedimentation using remote sensing and recommendations for desilting Patratu Reservoir, India. Hydrological Sciences Journal, 61(4), 711-718.

Patrington, K. C., 1998. Discrimination of glacier facies using multi-temporal SAR data. Journal of Glaciology, 44(146), pp. $42-53$.

Pekel, J., Cottam, A., Gorelick, N., and Belward, A.S., 2016. High-resolution mapping of global surface water and its longterm changes. Nature, 540, 418-422.

RGI Consortium, 2017. Randolph Glacier Inventory - A Dataset of Global Glacier Outlines: Version 6.0. GLIMS Technical Report RGI, 1(1), 1188-1197. https://doi.org/10.1111/j.1469-7610.2010.02280.x.

Saha, S.K. and Kumar, A.S., 2019. Northwest Himalayan Ecosystems: Issues, Challenges and Role of Geospatial Techniques. Chapter 1 in Book, Remote Sensing of Northwest Himalayan Ecosystems Editors: Navalgund, R.R., Kumar, Senthil, Nandy, Subrata (Eds.), 1st ed. 2019, LII, 564 p. 301. DOI: $10.1007 / 978-981-13-2128-3$. 
Scherler, D., Leprince, S. and Strecker, M. R., 2008. Glaciersurface velocities in alpine terrain from optical satellite imagery-Accuracy improvement and quality assessment. Remote Sensing of Environment, 112(10), 3806-3819.

Singh, P. and Jain, S.K., 2002. Snow and glacier melt in the Satluj River at Bhakra Dam in the Western Himalayan region. Hydrol Sci Journal. 47, 93-106.

Singh, V.P., 2018. Hydrologic modeling: progress and future directions. Geosci. Lett. 5, 15.

Subramaniam, S., Suresh Babu, A.V., Sivasankar, E., Venkateshwar Rao, V. and Behera, G., 2011. Snow Cover Estimation from Resourcesat-1 AWiFS -Image Processing With an Automated Approach. International Journal of Image Processing (IJIP), 5(3), 445-467.

Thakur, P. K., Aggarwal, S. P., Dhote P., Nikam, B. R., Garg, V., Bhatt, C. M., Chouksey, A. and Jha, A., 2019. Hydrometeorological Hazards Mapping, Monitoring and Modelling. Chapter 7 in Book, Remote Sensing of Northwest Himalayan Ecosystems Editors: Navalgund, R.R., Kumar, Senthil, Nandy, Subrata (Eds.), 1st ed. 2019, LII, 564 p. 301. DOI: $10.1007 / 978-981-13-2128-3$.

Thakur, P. K., Garg, V., Nikam, B. R., Singh, S., Jasmine, Chouksey, A., Dhote, P. R., Aggarwal, S. P., Chauhan, P., and Kumar, A. S., 2018. Snow Cover and Glacier Dynamics Study Using C-and L-Band SAR Datasets in Parts of North West Himalaya. Int. Arch. Photogramm. Remote Sens. Spatial Inf. Sci., XLII-5, 375-382. https://doi.org/10.5194/isprs-archivesXLII-5-375-2018.

Thakur, P.K., Aggarwal, S.P., Arun, G., Sood, S., Kumar, A.S., Mani, S. and Dobhal, D.P., 2017. Estimation of snow cover area, snow physical properties and glacier classification in parts of Western Himalaya using C-band SAR data. J Indian Soc Remote Sens., 45(3), 525-539.

U.S. National Ice Center. 2008, updated daily. IMS Daily Northern Hemisphere Snow and Ice Analysis at $1 \mathrm{~km}, 4 \mathrm{~km}$, and $24 \mathrm{~km}$ Resolutions, Version 1. [Global]. Boulder, Colorado USA. NSIDC: National Snow and Ice Data Center. doi: https://doi.org/10.7265/N52R3PMC. [Last accessed 10 Jan. 2020].

Vörösmarty, C.J., Sullivan, C.A., Davies, P.M., et al., 2010. Global threats to human water security and river biodiversity. Nature, 467, 555-561.

Wester, P., Mishra, A., Mukherji, A., et al., 2019. The Hindu Kush Himalaya Assessment, Mountains, Climate Change, Sustainability and People. Springer International Publishing, XXII, 627 pages. 10.1007/978-3-319-92288-1.

\section{APPENDIX - I}

Field photographs of snow, glaciers and DWLR measurements along with sample data from AWS/Snow sites.
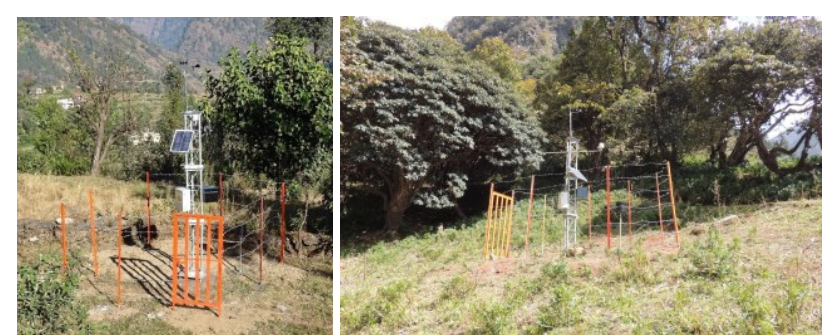

Figure 18. Installed AWSs at Guptkashi (Nov. 2016) and Dwali, Pindar valley (Oct. 2018), U.K.

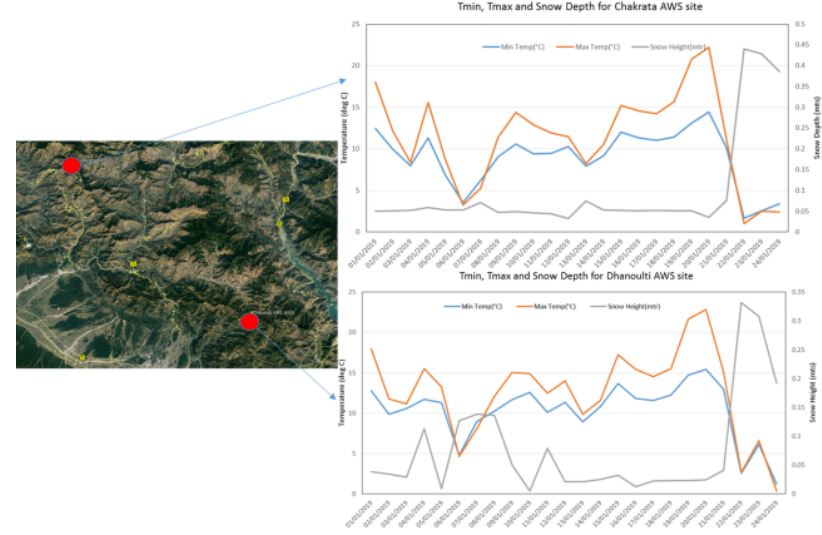

Figure 19. AWS data from Chakrata \& Dhanoulti stations of U.K. along with SD data for January 2019.
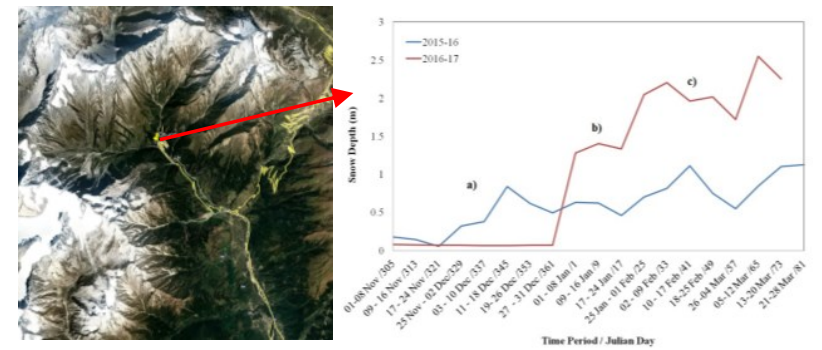

Figure 20. SPA at Dhundi \& SD data for 2016-17 winter seasons (SPA worked till Feb 2019, damaged in heavy snowfall of 2019, SD/SWE data from Oct.2015-Feb. 2019).

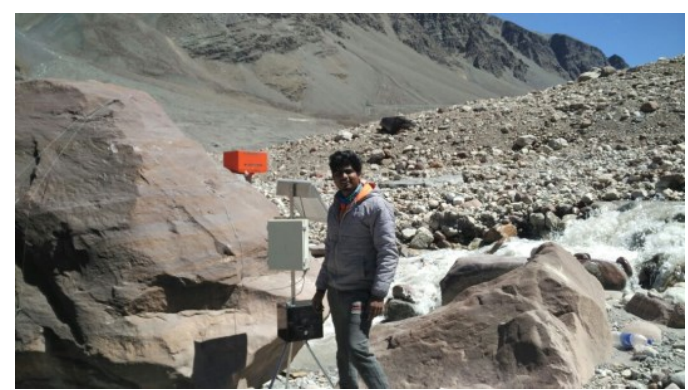

Figure 21. Installation of DWLR at downstream of Patsio glacier, H.P. (Oct. 2016). Instrument worked till April 2017, and was damaged due to heavy snowfall in 2017 winter season.

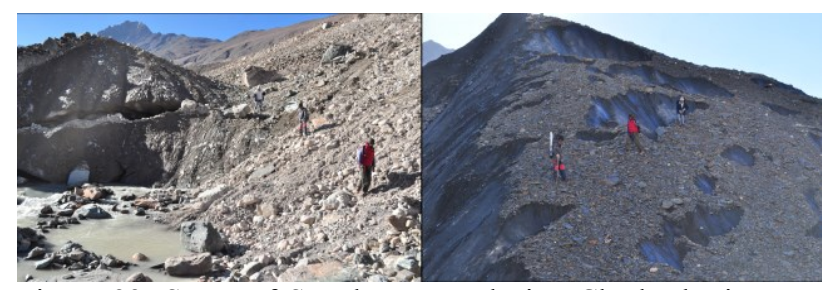

Figure 22. Snout of Smudra Tapu glacier, Chndra basin, H.P. with its end moraine lake and ice wall above snout (Credit: Praveen K. Thakur, glacier field campaign, Oct. 2013). 